\title{
IN VITRO ANTIOXIDANT ACTIVITIES OF AQUEOUS EXTRACTS DERIVED FROM LEAVES OF JUVENILE AND MATURE SHOOTS OF FICUS PUMILA L. (MORACEAE)
}

\author{
Tkachenko Halyna*1, Buyun Lyudmyla ${ }^{2}$, Kurhaluk Natalia ${ }^{1}$, \\ Honcharenko Vitaliy ${ }^{3}$, Prokopiv Andriy ${ }^{3,4}$, Osadowski Zbigniew ${ }^{1}$ \\ ${ }^{1}$ Institute of Biology and Earth Sciences, Pomeranian University in Słupsk, Poland \\ ${ }^{2}$ M.M. Gryshko National Botanic Garden, National Academy of Science of Ukraine, Kyiv, Ukraine \\ ${ }^{3}$ Ivan Franko National University in Lviv, Lviv, Ukraine \\ ${ }^{4}$ Botanic Garden of Ivan Franko National University in Lviv, Lviv, Ukraine
}

Received: 15.11.2019 Revised: 17.11.2019 Published: 28. 11.2019

The aim of this study was to investigate the in vitro antioxidant activity of aqueous extracts from the leaves developed on the shoots of various developmental stages (juvenile and mature/generative) of Ficus pumila L. using the oxidative stress biomarkers [2-thiobarbituric acid reactive substances (TBARS), carbonyl derivatives content of protein oxidative modification, total antioxidant capacity] on the equine erythrocytes' suspension model. Freshly collected leaves were washed, weighed, crushed, and homogenized in $0.1 \mathrm{M}$ phosphate buffer (pH 7.4) (in proportion $1: 19, \mathrm{w} / \mathrm{w}$ ). The equine erythrocyte aliquots were used in the study. A volume of $0.1 \mathrm{ml}$ of the $F$. pumila extract was added to $1.9 \mathrm{ml}$ of clean equine erythrocytes. For positive control (blank), phosphate buffer was used. The treatment with the extract obtained from leaves of mature shoots reduced the erythrocytes TBARS level by $22 \%$ ( $p=0.029)$, while TBARS level was increased by $15.5 \%(p>0.05)$ when incubated with an extract derived from leaves of juvenile shoots as compared to untreated erythrocytes. When equine erythrocytes were incubated with extract obtained from leaves of mature shoots, the ketonic derivatives level was significantly decreased by $6.9 \%(p=0.040)$, while non-significantly decrease both aldehydic and ketonic derivatives of OMP was observed after incubation with extract derived from juvenile shoots (by 8.18 and $12.5 \%, p>0.05$ ). The treatment by F. pumila leaf extract (from juvenile and mature shoots) caused the increase of TAC in erythrocyte suspension as compared to untreated erythrocytes. Thus, extracts derived from both juvenile and mature shoots resulted in an increase of total antioxidant capacity of equine erythrocytes' suspension.

Keywords: Ficus pumila L., leaf extract, equine erythrocytes, lipid peroxidation, oxidatively modified proteins, total antioxidant capacity

\footnotetext{
*Corresponding author: Halyna Tkachenko, Institute of Biology and Earth Sciences, Pomeranian University in Słupsk, Arciszewski 22b, 76-200 Słupsk, Poland

$\triangle$ tkachenko@apsl.edu.pl
} 


\section{Introduction}

Antioxidant compounds present in many plants, such as phenolic compounds (e.g. phenolic acids, flavonoids, quinones, coumarins, lignans, stilbenes, tannins), nitrogen compounds (alkaloids, amines, betalains), vitamins, terpenoids (including carotenoids), and some other endogenous metabolites, which are rich in antioxidant activity, can protect cells against damage caused by reactive oxygen species (ROS) (Cai et al., 2004; Das et al., 2014). A large number of medicinal plants have been investigated for their antioxidant properties. Natural antioxidants either in the form of raw extracts or their chemical constituents are very effective to prevent the destructive processes caused by oxidative stress (Akinmoladun et al., 2010).

Mopuri et al. (2018) have investigated the in vitro effects of the various parts of Ficus carica L. (fig) on antioxidant, antidiabetic, and antiobesogenic activity. The fruit ethanolic extract contained a high quantity of polyphenols and flavonoids compared with all other extracts. The activity of the ethanolic extract of $F$. carica fruit was significantly higher than all other extracts and parts of the plant in terms of antioxidative, antidiabetic, and antiobesogenic effects. The ethanolic extract of the fruit of $F$. carica may have potential antidiabetic and antiobesogenic agents. The research of Eshwarappa et al. (2015) highlights the chemical composition and antioxidant potential of leaf gall extracts (aqueous and methanol) of Ficus racemosa L. (syn. Ficus glomerata Roxb.), which is extensively used in the preparation of traditional medications to treat various metabolic diseases. Higher content of both total phenolics and flavonoids were found in the methanolic extract and the significantly high antioxidant activity can be positively correlated to the high content of total polyphenols/flavonoids of the methanol extract (Eshwarappa et al., 2015). In the study of Abrahim et al. (2018), the Ficus deltoidea Jack varieties have excellent antioxidant activity with no cytotoxic effects on normal liver cells. The leaves caused no signs of toxicity in a normal liver cell line. Misbah et al. (2013) have investigated the antidiabetic and antioxidant activities of the fruits from different varieties of $F$. deltoidea, employing in vitro methods. The antioxidant activities of the fruits of F. deltoidea might be asserted by the phenolic content but other polar plant components were possibly involved in the antidiabetic properties. The study of these compounds having both antihyperglycemic and antioxidant activities may provide a new approach in the treatment of diabetes mellitus (Misbah et al., 2013).

In our previous studies, in vitro protective effects of extracts obtained from various tropical and subtropical plants against hemolysis, lipid peroxidation, and oxidative damage of proteins in equine erythrocytes were evaluated (Tkachenko et al., 2017, 2018; Buyun et al., 2018). In case of Ficus genus, we have focused on the evaluation of antioxidant effect of leaf extract obtained from F. religiosa L. based on oxidative stress biomarkers [2-thiobarbituric acid reactive substances (TBARS), carbonyl derivatives content of protein oxidative modification (OMP), total antioxidant capacity (TAC)] using the equine erythrocytes model. Treatment by plant extract reduced the erythrocytes TBARS level by $25.3 \%(p=0.009)$, while plasma TBARS level was increased by $75.6 \%(p=0.000)$, as compared to untreated erythrocytes. When plasma was incubated with extract, the ketonic derivatives level was significantly increased by $22.8 \%$ ( $p=0.000$ ), while non significantly decrease both aldehydic and ketonic derivatives of OMP was observed. Treatment by F. religiosa extract caused the increase of TAC in plasma and 
erythrocyte suspension when compared to untreated erythrocytes. However, these changes were statistically non-significant. Consequently, all these data suggest that $F$. religiosa could be explored for its antioxidant potential (Tkachenko et al., 2018).

Hence, it becomes necessary to search new sources for noble antioxidants, especially those that would be safe and cheap and thus easily affordable by all populations. The present study was designed to investigate the oxidative stress biomarkers [2-thiobarbituric acid reactive substances (TBARS), carbonyl derivatives content of protein oxidative modification, total antioxidant capacity] using the equine erythrocytes' model to evaluate the antioxidant activities of the aqueous extracts of leaves derives from vegetative and mature shoots of Ficus pumila $\mathrm{L}$.

Ficus pumila is a climbing fig commonly used as an ornamental plant. It is reported to be native to East Asia, specifically South China through to Malaysia, but now it is cultivated in numerous countries around the world (Starr et al., 2003). It was reported that F. pumila is a very aggressive vine that rapidly grows on almost any surface, climbing by means of clusters of adventitious roots that emerge from internodes and sometimes form into an aggregate structure called an adhesive disk or pad (Groot et al., 2003).

Ficus pumila is a functionally dioecious species, i.e. it consists of female individuals with syconia which include only long-style female flowers and "male" individuals whose syconia include both male flowers and short-style flowers (Chen et al., 2008). The juvenile foliage is much smaller and thinner than mature leaves produced as the plant ages.

According to Yong et al. (2013), the leaves of this plant have antimicrobial, antileishmanial, and anti-inflammatory effects among many other medicinal benefits. These benefits could be attributed to the wide array of chemicals contained in it (Larbie et al., 2015). The Okinawan folks in Japan use F. pumila as a beverage or herbal medicine to treat diabetes and high blood pressure (Leong et al., 2008). The preparation of Ooitabi leaves in water provides a sufficient amount of flavonoid glycosides to the Okinawan although $50 \%$ of aqueous ethanol extracted these flavonoid glycosides more effectively. The potential of Ooitabi leaves as a natural source of antioxidants for health management was proved by Leong et al. (2008). Also, it was shown that the latex of $F$. pumila can cause phytophotodermatitis (Rademaker and Derraik, 2012), a toxic reaction caused by direct skin exposure to certain plant compounds, followed by exposure to ultraviolet (UV) light. Therefore, this plant, like all other ornamental Ficus spp. plants are very likely to contain certain important phytochemicals with pharmacological properties that could be useful (Larbie et al., 2015).

In this study, we report the data on the antioxidant properties of F. pumila in different plant parts (vegetative and mature shoots) to identify the plant part that gives the highest antioxidant activities and this may justify important ethno-medical uses of this medicinal plant as antioxidants possessing diverse biological actions. 


\section{Material and methodology}

\section{Collection of Plant Materials}

The leaves of F. pumila (juvenile and mature shoots) were collected in M.M. Gryshko National Botanic Garden (Kyiv, Ukraine) (Figure 1,2). The whole collection of tropical and subtropical plants at M.M. Gryshko National Botanic Garden (Kyiv, Ukraine) (including Ficus spp. plants) has the status of a National Heritage Collection of Ukraine. Plant samples were thoroughly washed to remove all the attached material and used to prepare extracts.

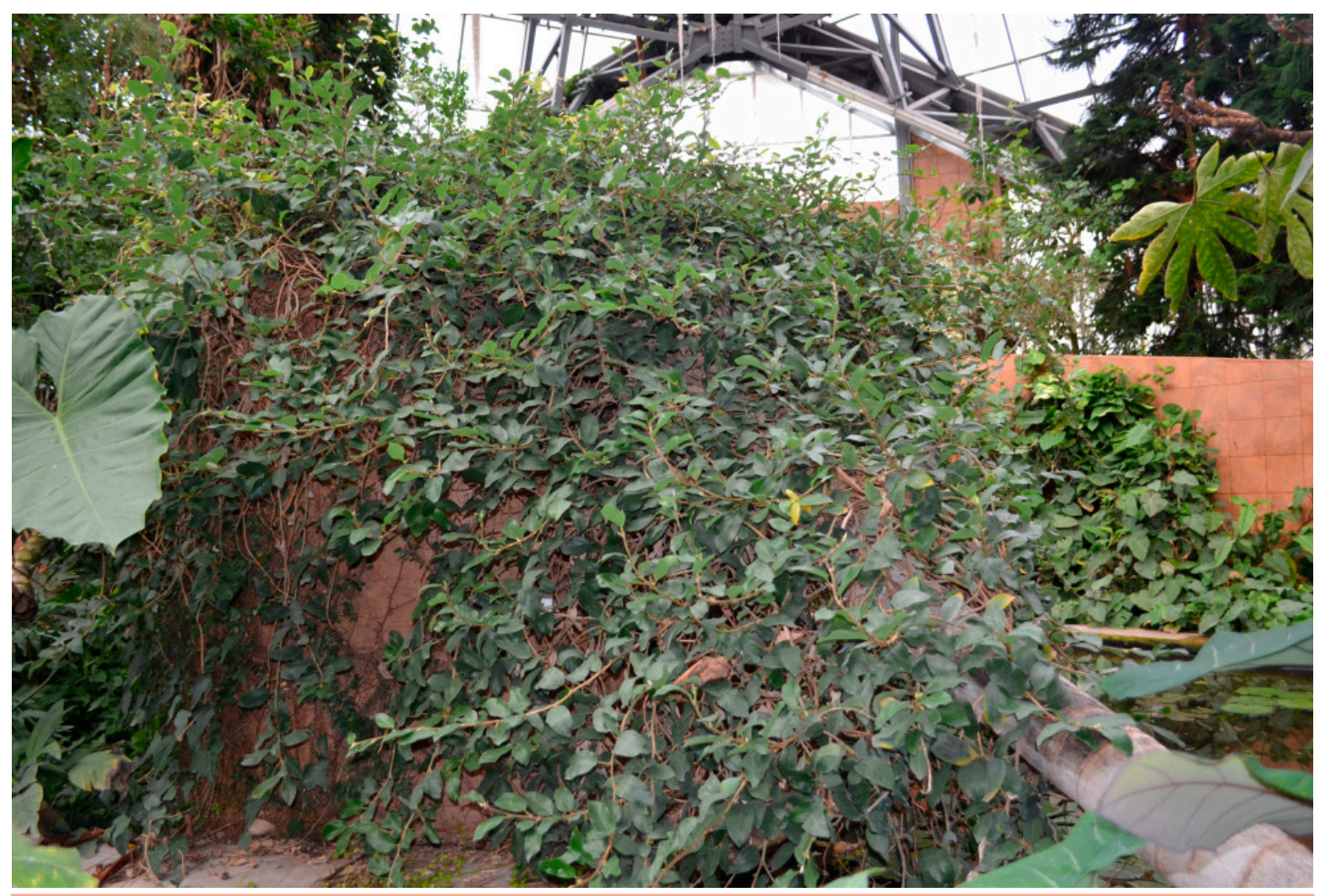

Figure 1

General view of Ficus pumila specimen with mature shoots climbing on the ventilation facility in the exhibition glasshouse at National Botanic Garden (Photo: Lyudmyla Buyun)

It is generally accepted that flowers and fruits rarely appear on indoor plants. Nevertheless, we have observed the pear-shaped fruits on the $F$. pumila plants cultivated under glasshouse conditions at NBG (Figure 2, B). However, we have not verified that this syconium included true long-style female flowers. Therefore in our study, we judged it appropriate to consider two different developmental stages of $F$. pumila shoots (juvenile and mature), taking into consideration rather morphological and morphometric characteristics of the leaves and shoots, but not plant individual sex differentiation (Figure 2A, 2B). 

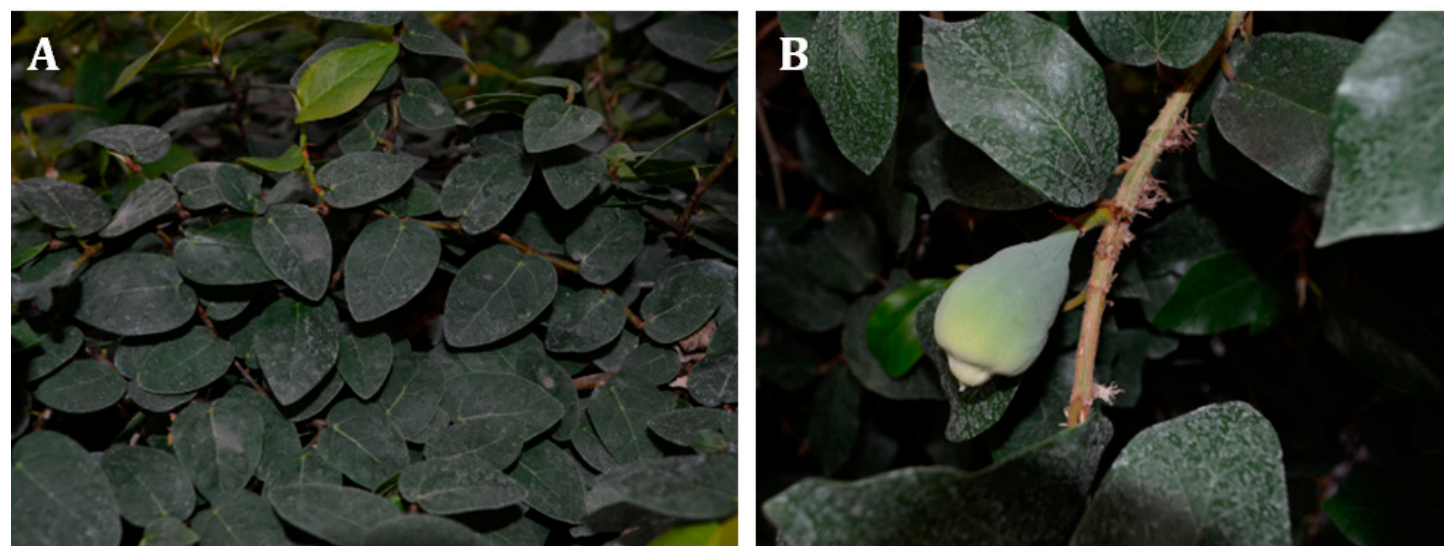

Figure 2

Leaf morphology of $F$. pumila (Photo: Lyudmyla Buyun)

A - shoot with juvenile leaves; B - fruit-bearing shoot with mature leaves

\section{Preparation of Plant Extracts}

Freshly collected leaves were washed, weighed, crushed, and homogenized in $0.1 \mathrm{M}$ phosphate buffer ( $\mathrm{pH}$ 7.4) (in proportion $1: 19, \mathrm{w} / \mathrm{w}$ ) at room temperature. The extracts were then filtered and used for analysis. All extracts were stored at $-20^{\circ} \mathrm{C}$ until use.

\section{Horses}

Eighteen clinically healthy adult horses from the central Pomeranian region in Poland (village Strzelinko, N 54ㅇ 30' 48.0” E 16 57' 44.9”), aged $8.9 \pm 1.3$ years old, including 6 Hucul pony, 5 Thoroughbred horses, 2 Anglo-Arabian horses and 5 horses of unknown breed, were used in this study. All horses participated in recreational horseback riding. Horses were housed in individual boxes, with feeding (hay and oat) provided twice a day, at 08.00 and $18.00 \mathrm{~h}$, and water available ad libitum. Before sampling, all horses were thoroughly examined clinically by a veterinarian and screened for hematological, biochemical and vital parameters, which were within reference ranges. The females were non-pregnant.

\section{Collection of blood samples}

Blood samples were collected in the morning, 90 minutes after feeding, while the horses were in the stables (between 8:30 and $10 \mathrm{AM}$ ) by jugular venipuncture into tubes with sodium citrate as the anticoagulant and held on the ice until centrifugation at 3,000 rpm for $5 \mathrm{~min}$ to remove plasma Blood was stored into The pellet of blood was resuspended in $4 \mathrm{mM}$ phosphate buffer ( $\mathrm{pH} 7.4$ ). A volume of $0.1 \mathrm{ml}$ of the plant extract was added to $1.9 \mathrm{ml}$ of clean equine erythrocytes. For positive control, phosphate buffer was used. After incubation of the mixture at $37^{\circ} \mathrm{C}$ for $60 \mathrm{~min}$ with continuous stirring, it was centrifuged at 3,000 rpm for 5 min. Erythrocytes aliquots were used in the study.

\section{The 2-Thiobarbituric acid reactive substances (TBARS) assay}

The level of lipid peroxidation was determined by quantifying the concentration of 2-thiobarbituric acid reacting substances (TBARS) with the Kamyshnikov (2004) method 
for determining the malonic dialdehyde (MDA) concentration. This method is based on the reaction of the degradation of the lipid peroxidation product, MDA, with 2-thiobarbituric acid (TBA) under high temperature and acidity to generate a colored adduct that is measured spectrophotometrically. The $\mu$ mol of per $1 \mathrm{~L}$ was calculated using $1.56 \cdot 10^{5} \mathrm{mM}^{1} / \mathrm{cm}^{1}$ as the extinction coefficient.

\section{The carbonyl derivatives content of protein oxidative modification (OMP) assay}

To evaluate the protective effects of the extract against free radical-induced protein damage in equine erythrocytes, a carbonyl derivatives content of protein oxidative modification (OMP) assay based on the spectrophotometric measurement of aldehydic and ketonic derivatives in the erythrocytes' suspension was performed. The rate of protein oxidative destruction was estimated from the reaction of the resultant carbonyl derivatives of amino acid reaction with 2.4-dinitrophenylhydrazine (DNFH) as described by Levine et al. (1990) and as modified by Dubinina et al. (1995). DNFH was used for determining carbonyl content in soluble and insoluble proteins. Carbonyl groups were determined spectrophotometrically from the difference in absorbance at $370 \mathrm{~nm}$ (aldehyde derivatives, $\mathrm{OMP}_{370}$ ) and $430 \mathrm{~nm}$ (ketonic derivatives, OMP430).

\section{Measurement of total antioxidant capacity (TAC)}

The TAC level in the sample was estimated by measuring the 2-thiobarbituric acid reactive substances (TBARS) level after Tween 80 oxidation. This level was determined spectrophotometrically at $532 \mathrm{~nm}$ (Galaktionova et al., 1998). Sample inhibits the $\mathrm{Fe}^{2+} /$ ascorbate-induced oxidation of Tween 80 , resulting in a decrease in the TBARS level. The level of TAC in the sample (\%) was calculated with respect to the absorbance of the blank sample.

\section{Statistical analysis}

The mean \pm S.E.M. values were calculated for each group to determine the significance of the intergroup difference. All variables were tested for normal distribution using the Kolmogorov-Smirnov and Lilliefors test $(p>0.05)$. The significance of differences between the total antioxidant capacity level (significance level, $p<0.05$ ) was examined using the Mann-Whitney $U$-test (Zar, 1999). In addition, the relationships between oxidative stress biomarkers were evaluated using Spearman's correlation analysis. All statistical calculations were performed on separate data from each individual with Statistica 8.0 software (StatSoft, Krakow, Poland).

\section{Results and discussion}

The TBARS content as a biomarker of lipid peroxidation in the equine erythrocytes suspension after in vitro incubation with $F$. pumila leaf extract (juvenile and mature shoots) was assessed and shown in Figure 3A. As can be seen in Figure 1A, treatment by extract obtained from leaves of mature shoots reduced the erythrocytes TBARS level by $22 \%$ ( $p=0.029$ ), while TBARS level was increased by $15.5 \%(p>0.05)$ when incubated with an extract derived from leaves of juvenile shoots as compared to untreated erythrocytes. 
Tkachenko, H., Buyun, L., Kurhaluk, N., Honcharenko, V., Prokopiv, A., Osadowski, Z.

Agr.bio.div. Impr. Nut., Health Life Qual., 2019, 1-13
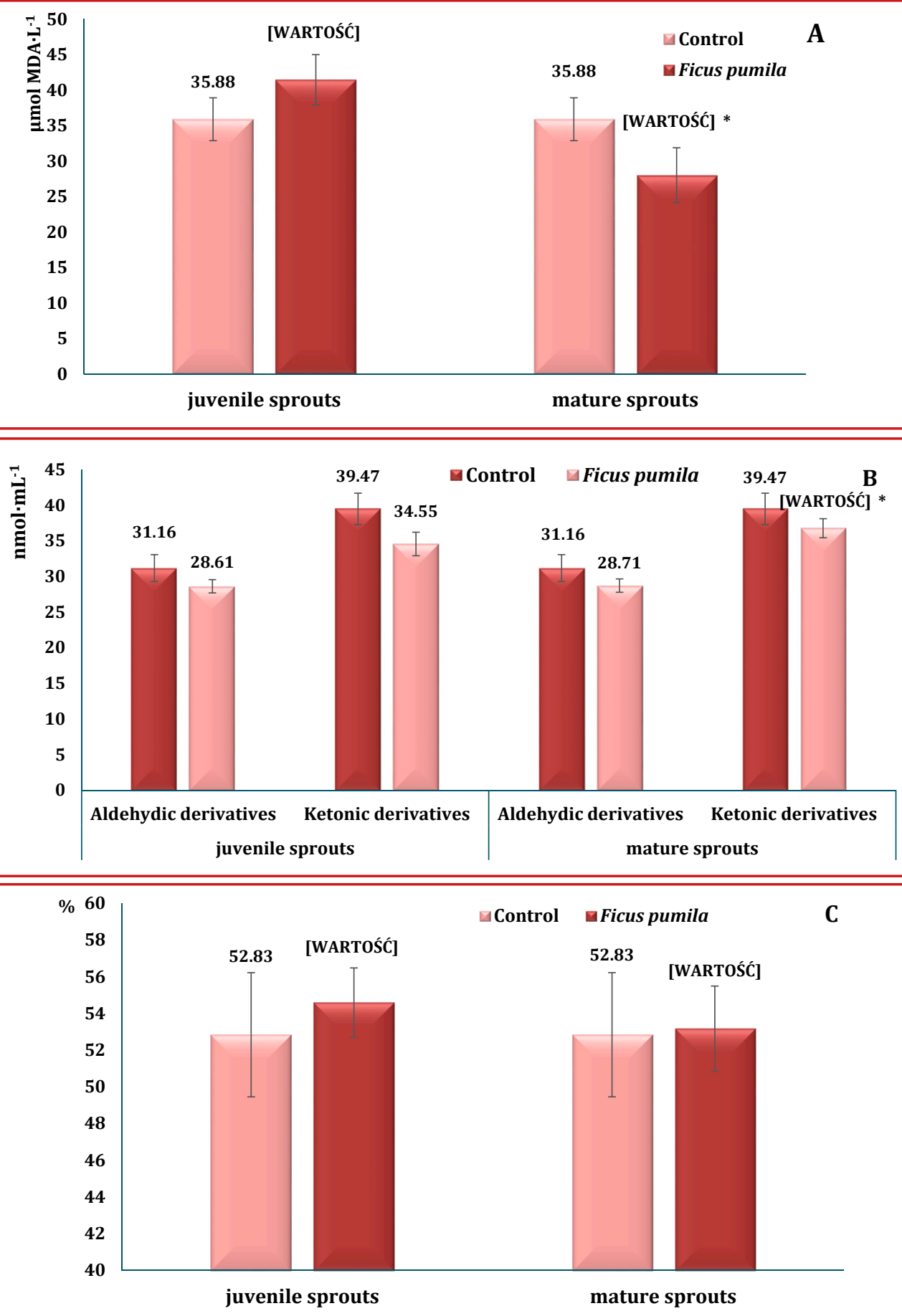

Figure 3 The TBARS content as a biomarker of lipid peroxidation (A), aldehydic and ketonic derivatives of oxidatively modified proteins (B), and total antioxidant capacity (C) in the equine erythrocytes' suspension after in vitro incubation with Ficus pumila leaf extract obtained from juvenile and mature shoots ( $\mathrm{M} \pm \mathrm{m}, n=18)$ 
When equine erythrocytes were incubated with extract obtained from leaves of mature shoots, the ketonic derivatives level was significantly decreased by $6.9 \%(p=0.040)$ (Figure 3B), while non-significantly decrease both aldehydic and ketonic derivatives of OMP was observed after incubation with extract derived from juvenile shoots (by 8.18 and $12.5 \%, p>0.05$ ).

As shown in Figure 3C, treatment by F. pumila leaf extract (juvenile and mature shoots) caused the increase of TAC in erythrocyte suspension when compared to untreated erythrocytes. However, these changes were statistically non-significant.

Several correlations between checked parameters were found (Figure 4). Erythrocyte TBARS level correlated positively with TAC level in the equine erythrocytes' suspension after in vitro incubation with $F$. pumila leaf extract obtained from mature shoots $(y=42.931+0.3655 \times x$; $r=0.609 ; p=0.0073 ; r^{2}=0.3713$ ) (Figure 4A). Decreased TBARS level induced the decrease of aldehydic derivatives of OMP in the equine erythrocytes' suspension after in vitro incubation with $F$. pumila leaf extract obtained from juvenile shoots $(y=-15.774+1.9995 \times x ; r=0.5254$; $\left.p=0.0252 ; r^{2}=0.2760\right)$. The ketonic derivatives of OMP correlated positively with aldehydic derivatives of OMP $\left(y=2.463+1.1215 \times x ; r=0.6342 ; p=0.0047 ; r^{2}=0.4021\right)$. The increased level of TAC in erythrocytes' suspension after incubation with leaf extract obtained from F. pumila (mature shoots) positively correlated with TAC level (Figure 4).

In the present study, we used an in vitro equine erythrocytes model to investigate the antioxidant effect of aqueous extract of $F$. pumila leaves. Many results also clearly suggest that treatment by herbal extracts in vivo and in vitro study prevents organ damage by a decrease of lipid peroxidation and protection of the antioxidant defense system. On this basis, the current investigation was conducted to evaluate the antioxidant effects of $F$. pumila leaf extract obtained from juvenile/vegetative and mature shoots. The main finding of this study was that the aqueous extract obtained from the mature shoots of $F$. pumila was able to decrease the lipid peroxidation and protein damage biomarkers in the equine erythrocytes' suspension after in vitro incubation.

Several methods have been developed to measure the free radical scavenging capacity, regardless of the individual compounds, which contribute towards the total capacity of a plant product in scavenging free radicals (Lo et al., 2004). For instance, Larbie et al. (2015) have determined the antiproliferative activity as well as phytochemicals content, total phenolic content (TPC), and antioxidant activity of the stem and leaf extracts (FPS and FPL) of F. pumila using standard methods. The hydroethanolic extracts of the leaves and stems were rich in tannins, general glycosides, saponins, terpenoids, alkaloids, flavonoids (leaves only), and sterols (stem only). Strong total antioxidant activities were observed with FPL and FPS with EC50 values of 0.07 and $0.089 \mathrm{mg} / \mathrm{ml}$, respectively. All the crude extracts showed an anti-proliferative effect on the three human leukemic cell lines used (Jurkat, CEM, and HL-60). However, FPL gave the strongest inhibition concentration at 50\% values of 130.97 (Jurkat) and $56.31 \mu \mathrm{g} / \mathrm{ml}$ (HL-60). These findings suggest that crude extracts of FPS and FPL have an anti-proliferative effect on the leukemia cells. The antioxidant properties of the plant including phenolics may be partly responsible for the anti-proliferative activity (Larbie et al., 2015). 
Tkachenko, H., Buyun, L., Kurhaluk, N., Honcharenko, V., Prokopiv, A., Osadowski, Z.

Agr.bio.div. Impr. Nut., Health Life Qual., 2019, 1-13

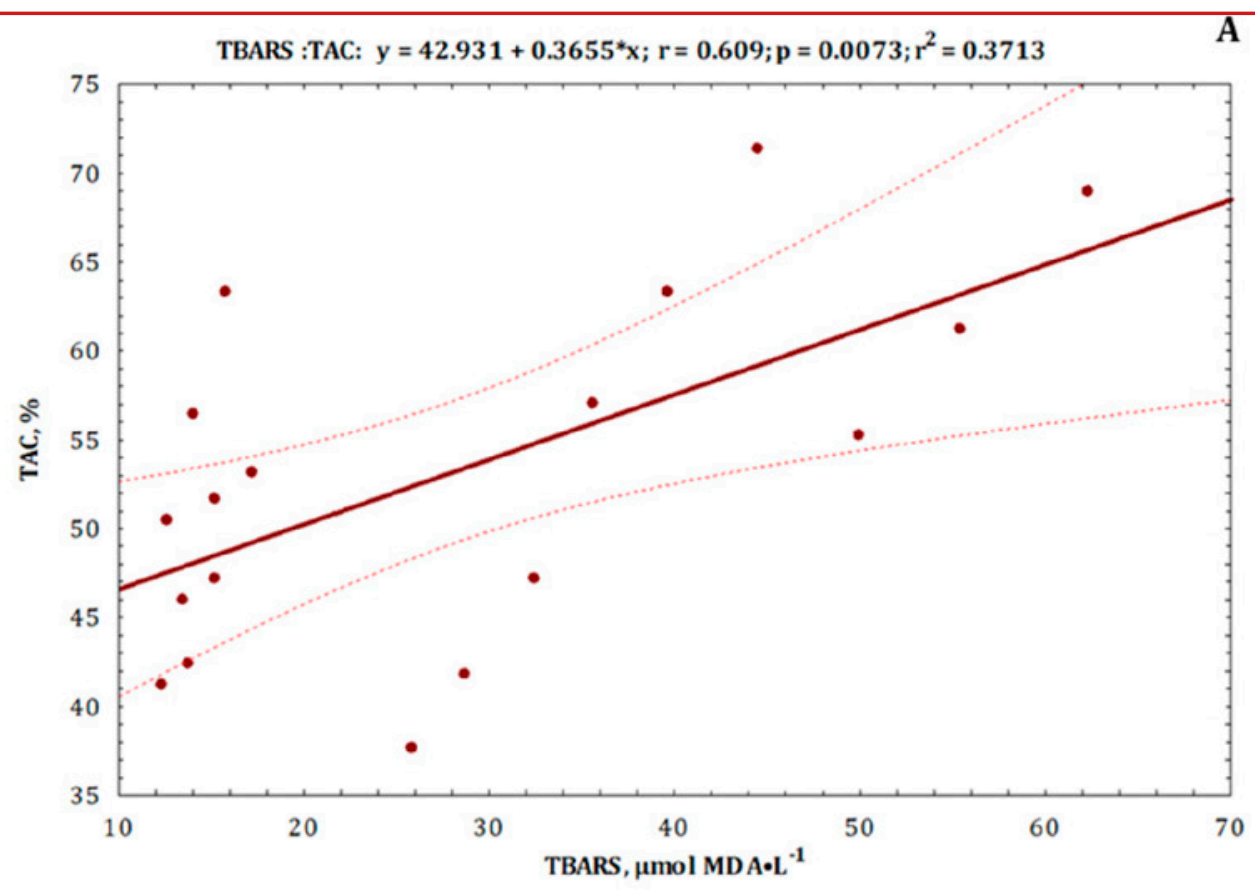

Aldehydic der ivatives of OMPTBARS: $y=-15.774+1.9995^{*} x ; r=0.5254 ; p=0.0252 ; r^{2}=0.2760$
Aldehydic derivatives of OMP. Ketonic derivatives of OMP. $y=2463+1.1215^{*} x ; r=0.6342 ; p=0.0047 ; r^{2}=0.4021$

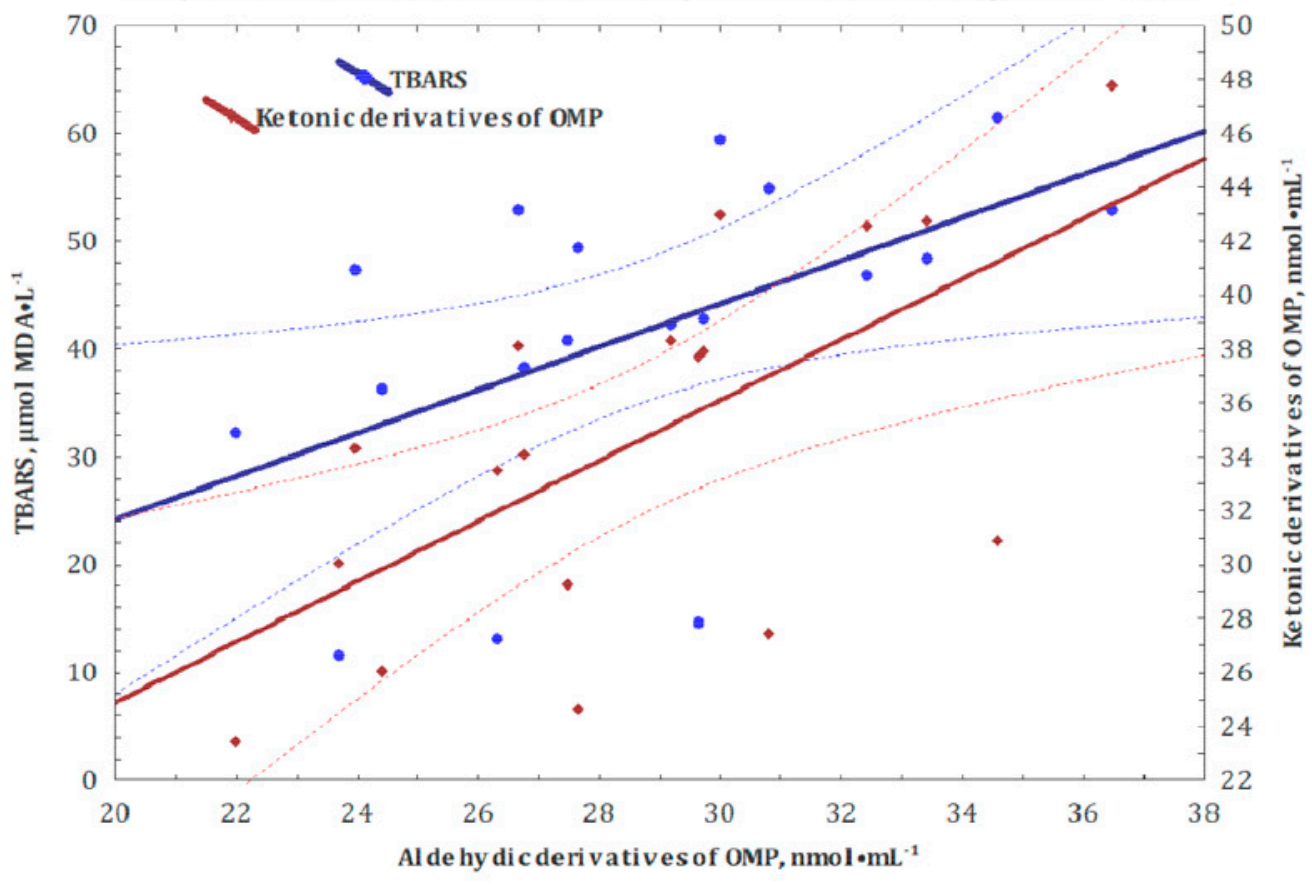

Figure 4 Correlations between oxidative stress biomarkers - TBARS and TAC level (A), aldehydic and ketonic derivatives of OMP and TAC level (B) in the equine erythrocytes' suspension after in vitro incubation with Ficus pumila leaf extract obtained from mature shoots (A) and juvenile shoots (B) 
Collectively, the current available data suggest that the phenolics present in plants belonging to the Ficus genus are important antioxidants because they have ideal structural chemistry for free radical scavenging activities, and have been shown to be more effective antioxidants in vitro than vitamins $\mathrm{E}$ and $\mathrm{C}$ on a molar basis (Ribeiro et al., 2008). Moreover, polyphenols exhibit a wide range of biological effects such as protection of lipid oxidation in vivo with significant consequences in atherosclerosis and also protect DNA from oxidative damage with important consequences in the age-related development of some cancers (Reddy et al., 2012; Das et al., 2014). Our findings suggested that leaves of $F$. pumila rich in antioxidant contents which are the major contributor to scavenge the free radicals in oxidation pathways.

We believe, that there is another important aspect in preliminary pharmacological studies of plants that should not be neglected. More than 15,000 angiosperm plant species are dioecious, i.e., having distinct male and female individuals (Seethapathy et al., 2018). The male and female plants also have remarkable differences in ecological adaptability, physiological and biochemical characteristics (Hultine et al., 2016; Li et al., 2016). The allocation of resources between male and female plants is different, and also variation in secondary metabolites is reported among dioecious plants (Li et al., 2016; Seethapathy et al., 2018). However, little is known about the ethnobotany of dioecious species and whether preferences exist in pharmacological investigations for a specific gender of plant samples screened for specific kinds of biological activity.

Consequently, in the current study, we have undertaken an attempt to investigate the in vitro antioxidant activity of extracts from the leaves developed on the shoots of various developmental stages (juvenile and mature/generative) of $F$. pumila plants.

The results obtained from the correlation between total antioxidant capacity and oxidative stress biomarkers suggested that antioxidant compounds are dominant contributors to the antioxidant activity of the extracts obtained from F. pumila leaves. Our future phytochemical screening of leaves also will reveal the presence of various classes of secondary metabolites which have great importance in medicinal chemistry and natural product research for their high antioxidant properties.

\section{Conclusions}

In the present study, analysis of oxidative stress biomarkers showed that the treatment by extract obtained from leaves of mature shoots of Ficus pumila reduced the lipid peroxidation and oxidatively modified protein contents in the equine erythrocytes. Extracts derived from both juvenile and mature shoots resulted in an increase of total antioxidant capacity of equine erythrocytes' suspension. However, further detailed investigation, especially in vivo and in vitro antioxidant and toxicity studies are needed to justify its use as a natural source of antioxidants.

\section{Acknowledgment}

This study was carried out during Scholarship Program supported by The Polish National Commission for UNESCO in the Institute of Biology and Earth Sciences, Pomeranian University in Slupsk (Poland). We thank The Polish National Commission for UNESCO for supporting our study. 


\section{References}

ABRAHIM, N.N., ABDUL-RAHMAN, P.S., AMINUDIN, N. 2018. The antioxidant activities, cytotoxic properties, and identification of water-soluble compounds of Ficus deltoidea leaves. In Peer J., vol. 6, p. e5694. https://doi.org/10.7717/peerj.5694

AHMED, M.M., ZAKI, N.I. 2009. Assessment the ameliorative effect of pomegranate and rutin on chlorpyrifos-ethyl-induced oxidative stress in rats. In Nature and Science, vol. 7(10), p. 49-61.

AKINMOLADUN, A.C., OBUOTOR, E.M., FAROMBI, E.O. 2010. Evaluation of antioxidant and free radical scavenging capacities of some Nigerian indigenous medicinal plants. In J. Med. Food, vol. 13(2), p. 444-451. https://doi.org/10.1089/jmf.2008.0292

AL-DHABI, N.A., ARASU, M.V., PARK, C.H., PARK, S.U. 2015. An up-to-date review of rutin and its biological and pharmacological activities. In EXCLIJ., vol. 14, p. 59-63. https://doi.org/10.17179/excli2014-663

AL-ENAZI, M.M. 2014. Protective effects of combined therapy of rutin with silymarin on experimentallyinduced diabetic neuropathy in rats. In Pharmacology \& Pharmacy, vol. 5(9), p. 876-889. https:// doi.org/10.4236/pp.2014.59098

BUBOLS, G.B., VIANNA, DDA, R., MEDINA-REMON, A., VON POSER, G., LAMUELA-RAVENTOS, R.M., EIFLER-LIMA, V.L., GARCIA, S.C. 2013. The antioxidant activity of coumarins and flavonoids. In Mini Rev. Med. Chem., vol. 13(3), p. 318-334. https://doi.org/10.2174/138955713804999775

BUYUN, L., TKACHENKO, H., OSADOWSKI, Z. 2018. In vitro assessment of antioxidant effect of Begonia rex Putz. leaf extract on oxidative stress biomarkers in the equine erythrocytes model. In Agrobiodiversity for Improving Nutrition, Health, and Life Quality, vol. 2, p. 94-110. https://doi. org/10.15414/agrobiodiversity.2018.2585-8246.094-110

CAI, Y., LUO, Q., SUN, M., CORKE, H. 2004. Antioxidant activity and phenolic compounds of 112 traditional Chinese medicinal plants associated with anticancer. In Life Sci., vol. 74(17), p. 2157-2184.

CHEN, Y., SHI, M.-M., AI, B., GU, J.-M., CHEN, X.-Y. 2008. Genetic variation in island and mainland populations of Ficus pumila (Moraceae) in eastern Zhejiang of China. In Symbiosis, vol. 45, p. 1-8.

DAS, N., ISLAM, M.E., JAHAN, N., ISLAM M.S., KHAN, A., ISLAM, M.R., PARVIN, M.S. 2014. Antioxidant activities of ethanol extracts and fractions of Crescentia cujete leaves and stem bark and the involvement of phenolic compounds. In BMC Complement. Altern. Med., vol. 14, p. 45. https://doi. org/10.1186/1472-6882-14-45

DUBININA, E.E., BURMISTROV, S.O., KHODOV, D.A., POROTOV, I.G. 1995. Oxidative modification of human serum proteins. A method of determining it. In Voprosy Meditsinskoĭ Khimii, vol. 41, p. 24-26 (In Russian).

ENOGIERU, A.B., HAYLETT, W., HISS, D.C., BARDIEN, S., EKPO, O.E. 2018. Rutin as a Potent Antioxidant: Implications for Neurodegenerative Disorders. In Oxid. Med. Cell Longev., 2018, ID 6241017. https://doi.org/10.1155/2018/6241017

ESHWARAPPA, R.S., IYER, S., SUBARAMAIHHA, S.R., RICHARD, S.A., DHANANJAYA, B.L. 2015. Antioxidant activities of Ficus glomerata (moraceae) leaf gall extracts. In Pharmacognosy Res., vol. 7(1), p. 114120. https://doi.org/10.4103/0974-8490.147225

FYLAKTAKIDOU, K.C., HADJIPAVLOU-LITINA, D.J., LITINAS, K.E., NICOLAIDES, D.N. 2004. Natural and synthetic coumarin derivatives with anti-inflammatory/ antioxidant activities. In Curr. Pharm. Des., vol. 10(30), p. 3813-3833. https://doi.org/10.2174/1381612043382710

GALAKTIONOVA, L.P., MOLCHANOV, A.V., EL'CHANINOVA, S.A., VARSHAVSKIĬ, B., 1998. Lipid peroxidation in patients with gastric and duodenal ulcers. In Klinicheskaia Labaratornaia Diagnostika, vol. 6, p. 10-14 (In Russian).

GROOT, E.P., ROST, T., SWEENEY, E.J. 2003. Development of the adhesive pad on climbing fig (Ficus pumila) stems from clusters of adventitious roots. In Plant and Soil, vol. 248(1), p. 85-96. https:// doi.org/10.1023/A:1022342025447

HANASAKI, Y., OGAWA, S., FUKUI, S. 1994. The correlation between active oxygens scavenging and antioxidative effects of flavonoids. In Free Radic. Biol. Med., vol. 16(6), p. 845-850. https://doi. org/10.1016/0891-5849(94)90202-x 
HOULT, J.R., PAYÁ, M. 1996. Pharmacological and biochemical actions of simple coumarins: natural products with therapeutic potential. In Gen. Pharmacol., vol. 27(4), p. 713-722. https://doi. org/10.1016/0306-3623(95)02112-4

HULTINE, K.R., GRADY, K.C., WOOD, T.E., SHUSTER, S.M., STELLA, J.C., WHITHAM, T.G. 2016. Climate change perils for dioecious plant species. In Nature Plants, vol. 2(8), p. 16109. https://doi. org/10.1038/NPLANTS.2016.109

JUAN, E.A., RIDEOUT, J.A., RAGASA, C.Y. 1997. Bioactive furanocoumarin derivatives from Ficus pumila (Moraceae). In Philipp. J. Sci., vol. 126, p. 143-153.

KAMYSHNIKOV, V.S. 2004. A reference book on the clinic and biochemical researches and laboratory diagnostics. MEDpress-inform, Moscow.

KITAJIMA, J., KIMIZUKA, K., TANAKA, Y. 2000. Three new sesquiterpenoid glucosides of Ficus pumila fruit. In Chem. Pharm. Bull. (Tokyo), vol. 48, p. 77-80. https://doi.org/10.1248/cpb.48.77

KOSTIĆ, D.A., DIMITRIJEVIĆ, D.S., STOJANOVIĆ, G.S., PALIĆ, I.R., ĐORĐEVIĆ, A.S., ICKOVSKI, J.D. 2015. Xanthine oxidase: isolation, assays of activity, and inhibition. In Journal of Chemistry, p. 8. https:// doi.org/10.1155/2015/294858.294858

LARBIE, C., APPIAH-OPONG, R., ACHEAMPONG, F., TUFFOUR, I., UTO, T., AGYARE YEBOAH, G., ABBOAHOFFEI, O., TAGOE, D.N.K., INKABI, S.E. 2015. Anti-proliferative effect of Ficus pumila Linn. on human leukemic cell lines. In International Journal of Basic \& Clinical Pharmacology, vol. 4(2), p. 330-336. https://doi.org/10.5455/2319-2003.ijbcp20150434

LEONG, C.N., TAKO, M., HANASHIRO, I., TAMAKI, H. 2008. Antioxidant flavonoid glycosides from the leaves of Ficus pumila L. In Food Chem., vol. 109(2), p. 415-420. https://doi.org/10.1016/j. foodchem.2007.12.069

LEVINE, R.L., GARLAND, D., OLIVER, C.N., AMIC, A., CLIMENT, I., LENZ, A.G., AHN, B.W., SHALTIEL, S., STADTMAN, E.R. 1990. Determination of carbonyl content in oxidatively modified proteins. In Methods in Enzymology, vol. 186, p. 464-478. https://doi.org/10.1016/0076-6879(90)86141-H

LI, X., JIANG, S., MAN, C. 2016. Metabolomic analysis of female and male plants of Pistacia chinensis Bunge. In Pak. J. Bot., vol. 48(5), p. 1971-1977.

LO, S.F., NALAWADE, S.M., MULABAGAL, V., MATTHEW, S., CHEN, C.L., KUO, C.L., TSAY, H.S. 2004. In vitro propagation by asymbiotic seed germination and 1.1-diphenyl-2-picrylhydrazyl (DPPH) radical scavenging activity studies of tissue culture raised plants of three medicinally important species of dendrobium. In Biol. Pharm. Bull., vol. 27(5), p. 731-735. https://doi.org/10.1248/bpb.27.731

MAGALINGAM, K.B., RADHAKRISHNAN, A., HALEAGRAHARA, N. 2013. Rutin, a bioflavonoid antioxidant protects rat pheochromocytoma (PC-12) cells against 6-hydroxydopamine (6-OHDA)-induced neurotoxicity. In J. Mol. Med., vol. 32(1), p. 235-240. https://doi.org/10.3892/ijmm.2013.1375

MISBAH, H., AZIZ, A.A., AMINUDIN, N. 2013. Antidiabetic and antioxidant properties of Ficus deltoidea fruit extracts and fractions. In BMC Complement. Altern. Med., vol. 13, p. 118. https://doi. org/10.1186/1472-6882-13-118

MOPURI, R., GANJAYI, M., MERIGA, B., KOORBANALLY, N.A., ISLAM, M.S. 2018. The effects of Ficus carica on the activity of enzymes related to metabolic syndrome. In J. Food Drug Anal., vol. 26(1), p. 201210. https://doi.org/10.1016/j.jfda.2017.03.001

MOURE, A., CRUZ, J.M., FRANCO, D., DOMINGUEZ, J.M., SINEIRO, J., DOMINGUEZ, H., NUNEZ, M.J., PARJO, J.C. 2001. Natural antioxidants from residual sources. In Food Chem., vol. 72, p. 145-171. https:// doi.org/10.1016/S0308-8146(00)00223-5

NAJMANOVÁ, I., DOSEDĚL, M., HRDINA, R., ANZENBACHER, P., FILIPSKÝ, T., ŘÍHA, M., MLADĚNKA, P. 2015. Cardiovascular effects of coumarins besides their antioxidant activity. In Curr. Top. Med. Chem., vol. 15(9), p. 830-849. https://doi.org/10.2174/1568026615666150220112437

PEREIRA, T.M., FRANCO, D.P., VITORIO, F., KUMMERLE, A.E. 2018. Coumarin Compounds in Medicinal Chemistry: Some Important Examples from the Last Years. In Curr. Top. Med. Chem., vol. 18(2), p. 124-148. https://doi.org/10.2174/1568026618666180329115523 
PERK, A.A., SHATYNSKA-MYTSYK, I., GERÇEK, Y.C., BOZTAȘ, K., YAZGAN, M., FAYYAZ, S., FAROOQI, A.A. 2014. Rutin mediated targeting of signaling machinery in cancer cells. In Cancer Cell Int., vol. 14(1), p. 124. https://doi.org/10.1186/s12935-014-0124-6

PISTELLI, L., CHIELLINI, E.E., MORELLI, I. 2000. Flavonoids from Ficus pumila. In Biochemical Systematics and Ecology, vol. 28(3), p. 287-289. https://doi.org/10.1016/S0305-1978(99)00064-2

RADEMAKER, M., DERRAIK, J.G.B. 2012. Phytophotodermatitis caused by Ficus pumila. In Contact Dermatitis, vol. 67(1), p. 53-56. https://doi.org/10.1111/j.1600-0536.2012.02026.x

RAGASA, C.Y., JUAN, E., RIDEOUT, J.A. 1999. A triterpene from Ficus pumila. In J. Asian Nat. Prod. Res., vol. 1, p. 269-275. https://doi.org/10.1080/10286029908039875

REDDY, N.S., NAVANESAN, S., SINNIAH, S.K., WAHAB, N.A., SIM, K.S. 2012. Phenolic content, antioxidant effect and cytotoxic activity of Leea indica leaves. In BMC Complement. Altern. Med., vol. 12, p. 128. https://doi.org/10.1186/1472-6882-12-128

RIBEIRO, S.M.R., BARBOSA, L.C.A., QUEIROZ, J., KNODLER, H.M., SCHIEBER, A. 2008. Phenolic compounds and antioxidant capacity of Brazilian mango (Mangifera indica L.) varieties. In Food Chem., vol. 110, p. 620-626. https://doi.org/10.1016/j.foodchem.2008.02.067

SEETHAPATHY, G.S., RAVICUMAR, K., PAULSEN, B.S., DE BOER, H.J., WANGENSTEEN, H. 2018. Ethnobotany of dioecious species: Traditional knowledge on dioecious plants in India. In J. Ethnopharmacol., vol. 221, p. 56-64. https://doi.org/10.1016/j.jep.2018.04.011

STARR, F., STARR, K., LOOPE, L. 2003. Ficus pumila. United States Geological Survey, Biological Resources Division Haleakala Field Station, Maui, Hawaii.

TKACHENKO, H., BUYUN, L., MARYNIUK, M., OSADOWSKI, Z. 2018. A comparative study of effect of various Sansevieria Thunb. leaf extracts on the lipid peroxidation in the equine erythrocyte suspension. In Agrobiodiversity for Improving Nutrition, Health, and Life Quality, vol. 2, p. 69-81. https://doi.org/10.15414/agrobiodiversity.2018.2585-8246.069-081

TKACHENKO, H., BUYUN, L., OSADOWSKI, Z., HONCHARENKO, V., PROKOPIV, A. 2018. Oxidative stress biomarkers in the equine plasma and erythrocytes treated in vitro by leaf extract obtained from Ficus religiosa L. (Moraceae). In Agrobiodiversity for Improving Nutrition, Health, and Life Quality, vol. 2, p. 184-200. https://doi.org/10.15414/agrobiodiversity.2018.2585-8246.184-200

TKACHENKO, H., BUYUN, L., PAŻONTKA-LIPIŃSKI, P., WITASZEK, M., OSADOWSKI, Z. 2017. In vitro protective effect of extracts obtained from various Sansevieria species against oxidative damage of proteins in equine erythrocytes. In Słupskie Prace Biologiczne, vol. 14, p. 271-290.

TKACHENKO, H., BUYUN, L., WITASZEK, M., PAŻONTKA-LIPIŃSKI, P., OSADOWSKI, Z. 2017. Hemolysis of equine erythrocytes from exposure to leaf extracts obtained from various Begonia L. species. In Słupskie Prace Biologiczne, vol. 14, p. 253-270.

TORRES, F.C., BRUCKER, N., ANDRADE, S.F., KAWANO, D.F., GARCIA, S.C., POSER, G.L., EIFLER-LIMA, V.L. 2014. New insights into the chemistry and antioxidant activity of coumarins. In Curr. Top. Med. Chem., vol. 14(22), p. 2600-2623. https://doi.org/10.2174/1568026614666141203144551

WEN, L., ZHAO, Y., JIANG, Y., YU, L., ZENG, X., YANG, J., TIAN, M., LIU, H., YANG, B. 2017. Identification of a flavonoid C-glycoside as potent antioxidant. In Free Radic. Biol. Med., vol. 110, p. 92-101. https:// doi.org/10.1016/j.freeradbiomed.2017.05.027

WU, J., CHEN, M., SHI, S., WANG, H., LI, N., SU, J., LIU, R., HUANG, Z., JIN, H., JI, X., WANG, S. 2017. Hypoglycemic effect and mechanism of a pectic polysaccharide with hexenuronic acid from the fruits of Ficus pumila L. In C57BL/KsJ db/db mice. In Carbohydr. Polym., vol. 178, p. 209-220. https://doi.org/10.1016/j.carbpol.2017.09.050

YONG, Y.K., ZAKARIA, Z.A., KADIR, A.A., SOMCHIT, M.N., CHENG E.E., LIAN, G., AHMAD, Z. 2013. Chemical constituents and antihistamine activity of Bixa orellana leaf extract. In BMC Complement. Altern. Med., vol. 13, p. 32-38. https://doi.org/10.1186/1472-6882-13-32

ZAR, J.H. 1999. Biostatistical Analysis. $4^{\text {th }}$ ed., Prentice-Hall Inc., Englewood Cliffs, New Jersey. 